\title{
TFP5 prevents 1-methyl-4-phenyl pyridine ion-induced neurotoxicity in mouse cortical neurons
}

\author{
QI-SHAN ZHANG ${ }^{1,2}$, YUAN-GAO LIAO ${ }^{1,2}$, ZHONG JI $^{1}$, YONG GU ${ }^{1}$, HAI-SHAN JIANG ${ }^{1}$, \\ ZUO-SHAN XIE ${ }^{1}$, SU-YUE PAN ${ }^{1}$ and YA-FANG HU ${ }^{1}$ \\ ${ }^{1}$ Department of Neurology, Nanfang Hospital, Southern Medical University, Guangzhou, Guangdong 510515; \\ ${ }^{2}$ Department of Neurology, Chenzhou First People's Hospital, Chenzhou, Hunan 423000, P.R. China
}

Received June 16, 2015; Accepted July 28, 2016

DOI: $10.3892 / \mathrm{etm} .2016 .3658$

\begin{abstract}
The present study aimed to investigate the protective effect of a modified p5 peptide, TFP5, on 1-methyl-4-phenyl pyridine ion $\left(\mathrm{MPP}^{+}\right)$-induced neurotoxicity in cortical neurons and explore the therapeutic effect of TFP5 on Parkinson's disease (PD). $\mathrm{MPP}^{+}$was applied to a primary culture of mouse cortical neurons to establish the cell model of PD. Neurons were divided into four groups: Control, model $\left(\mathrm{MPP}^{+}\right)$, scrambled peptide $(\mathrm{Scb})\left(\mathrm{Scb}+\mathrm{MPP}^{+}\right)$and TFP5 $\left(\mathrm{TFP} 5+\mathrm{MPP}^{+}\right)$groups. Pretreatment with Scb or TFP5 was applied to the latter two groups, respectively, for $3 \mathrm{~h}$, while phosphate-buffered saline was applied to the control and model groups. $\mathrm{MPP}^{+}$was then applied to all groups, with the exception of the control group, and neurons were cultured for an additional $24 \mathrm{~h}$. Neuron viability was evaluated using a Cell Counting kit-8 (CCK8) assay. To explore the mechanism underlying the protective effects of TFP5, the expression levels of p35, p25 and phosphorylated myocyte enhancer factor 2 (p-MEF2D) were determined by western blotting. Fluorescence microscopy showed that TFP5 was able to pass through cell membranes and distribute around the nucleus. CCK8 assay showed that neuronal apoptosis was dependent on $\mathrm{MPP}^{+}$ concentration and exposure time. Cell viability decreased significantly in the model group compared with the control group (55 \pm 7 vs. $100 \pm 0 \%$; $\mathrm{P}<0.01$ ), and increased significantly in the TFP5 group compared with the model group (98 \pm 2 vs. $55 \pm 5 \% ; \mathrm{P}<0.01)$ and Scb group (98 \pm 2 vs. $54 \pm 4 \% ; \mathrm{P}<0.01)$. Scb exhibited no protective effect. Western blotting results showed that $\mathrm{MPP}^{+}$induced p25 and p-MEF2D expression, TFP5 and Scb did not affect $\mathrm{MPP}^{+}$-induced p25 expression, but TFP5 reduced $\mathrm{MPP}^{+}$-induced $\mathrm{p}-\mathrm{MEF} 2 \mathrm{D}$ expression. In summary,
\end{abstract}

Correspondence to: Professor Ya-Fang Hu, Department of Neurology, Nanfang Hospital, Southern Medical University, 1838 North Guangzhou Avenue, Guangzhou, Guangdong 510515, P.R. China

E-mail: yafanghu82@163.com

Key words: Parkinson's disease, cyclin-dependent kinase 5, truncated peptide, mouse cortical neurons, neurotoxicity
TFP5 protects against $\mathrm{MPP}^{+}$-induced neurotoxicity in mouse cortical neurons, possibly through inhibiting the $\mathrm{MPP}^{+}$-induced formation and elevated kinase activity of a cyclin-dependent kinase 5/p25 complex.

\section{Introduction}

The exact cause of Parkinson disease (PD) is poorly understood, even though nearly 200 years has passed since James Parkinson first described PD in 1817, and the treatment is limited to maintaining the balance of dopamine and cholinergic transmitter through the administration of L-dopa, inhibitors of L-dopa decarboxylase, dopaminergic agonists and/or monoamine oxidase B inhibitors $(1,2)$. These measures are only symptom-relieving options, and cannot prevent the neuronal degenerative process. Therefore, the exploration of new therapeutic targets is necessary.

Cyclin-dependent kinase $5(\mathrm{Cdk} 5)$ is a unique cell cycle kinase homolog that exhibits serine/threonine kinase activity in the brain (3). Complexing with its activator, p35, Cdk5 is essential for early neurodevelopment in mammals $(4,5)$. However, endogenous calpain-dependent cleavage of p35 to p25 is associated with neuron death and neurodegenerative disease as the product p25 aberrantly activates Cdk5 and has a long half-life (6). Studies have found that the Cdk5/p25 complex is involved in dopaminergic neuron loss in the substantia nigra pars compacta (SNpc), which is responsible for the symptoms of PD patients and animal models (7-10). This occurs through the hyper-phosphorylation of several substrates involved in $\mathrm{PD}$, such as the neuronal survival factor myocyte enhancer factor 2 (MEF2) (11), Parkin (10), EndoB1 (9) and Raf kinase inhibitor protein (RKIP) (10).

Treatments targeted at the modification of Cdk5 activity include $\mathrm{Cdk}$ inhibitors such as roscovitine, and calpain inhibitors such as kenpaullone and induribins (12). However, these drugs lack specificity and also inhibit normal Cdk5/p35 activity and other Cdks essential for normal development and function. This may lead to serious side effects and thereby reduce the clinical value. Addressing this problem, the use of truncated peptides from p35 that can specifically inhibit $\mathrm{Cdk} 5 / \mathrm{p} 25$ formation and aberrant activity is a promising approach. A peptide (p10') encoding the N-terminal domain of p35 has been shown to prevent the death of neurons exposed 
to the neurotoxic 1-methyl-4-phenylpyridinium ion $\left(\mathrm{MPP}^{+}\right)$, which induces the conversion of endogenous p35 to p25 (13). Another short peptide [amino acid residues 154-279; Cdk5 inhibitory peptide (CIP)] derived from p35, also inhibits $\mathrm{Cdk} 5 / \mathrm{p} 25$ activity in neurons without affecting $\mathrm{Cdk} 5 / \mathrm{p} 35$ activity $(14,15)$. To address the problem that p10' and CIP are too large for successful therapeutic regimens, a smaller peptide, p5, spanning CIP residues Lys245-Ala277, was developed and is able to reduce amyloid $\beta$-induced tau hyperphosphorylation and the apoptosis of cortical neurons without effecting endogenous Cdk5/p35 activity (16). To facilitate passage through the blood-brain barrier, p5 peptide has been modified by conjugating an 11-amino acid peptide derived from transactivator of transcription (Tat) protein at the $\mathrm{C}$ terminus and attaching fluorescein isothiocyanate (FITC; a green fluorescent tag) with a linker (GGG) at the $\mathrm{N}$ terminus (17). This modified peptide is known as TFP5, and intraperitoneal injections of TFP5 into mutant mice have been shown to rescue behavioral and motor deficits in an Alzheimer's disease (AD) transgenic mouse model (17). Furthermore, TFP5 treatment reduces Cdk5/p25 hyperactivity significantly and, in turn decreases tau hyperphosphorylation, phospho-neurofilament proteins, plaques and gliosis in the brain (18).

Encouraged by the aforementioned successful results obtained with TFP5, and since $\mathrm{Cdk} 5 / \mathrm{p} 25$ plays a critical role in the nigrostriatal degeneration of PD patients and animal models, the present study aimed to test the protective function of TFP5 on $\mathrm{MPP}^{+}$-induced neurotoxicity in primary mouse cortical neurons and explore the possible therapeutic effect of TFP5 on PD.

\section{Materials and methods}

Reagents. $\mathrm{MPP}^{+}$was purchased from Sigma-Aldrich (Merck Millipore, Darmstadt, Germany). TFP5 (FITC-GGGKEA FWDRCLSVINLMSSKMLQINAYARAARRAARR) and scrambled (Scb) TFP5 peptide (Scb peptide; FITC-GGGGGG FWDRCLSGKGKMSSKGGGINAYARAARRAARR) were synthesized by Qiangyao Biotechnology Co., Ltd. (Shanghai, China). All drugs were dissolved in phosphate-buffered saline (PBS) and applied to primary mice neuron culture.

In vitro PD model establishment and treatment. Primary cortical neuron cultures were prepared from C57BL/6 mouse embryos at embryonic day 18 and maintained as previously described (19). Mice were purchased from the Laboratory Animal Center of Southern Medical University (Guangzhou, China) and all animal procedures were approved by the University Committee on Animal Care of Southern Medical University [certificate No. SCXK (Yue) 2006-0015] and conducted in accordance with the Guide for the Care and Use of Laboratory Animals (8th edition, 2011).

Briefly, forebrains were isolated, the hippocampus and the midbrain were removed, cortical tissue was obtained and the meninges and blood vessels on it were stripped. All above procedures were processed in medium comprising 1X HBSS (Gibco; Thermo Fisher Scientific, Inc., Waltham, MA, USA), $10 \mathrm{ml}$ HEPES (pH 7.3) and $10 \mathrm{ml} 100 \mathrm{X}$ penicillin/streptomycin (Gibco; Thermo Fisher Scientific, Inc.) placed on ice. The cortical tissue was then cut into small pieces and incubated with papain at $37^{\circ} \mathrm{C}$ for $30 \mathrm{~min}$. Following this, it was digested for 20-30 sec with $200 \mu \mathrm{l}$ DNA enzyme I, neutralized with $20 \mathrm{ml} \mathrm{10 \%}$ glial minimum essential media (MEM; Hyclone; GE Healthcare Life Sciences, Logan, USA), then dispersed by repeated aspiration with a Pasteur pipette. Finally, tissue was homogenized in 10\% modified glial MEM (425 ml MEM, $15 \mathrm{ml} \mathrm{20 \%}$ glucose, $5 \mathrm{ml}$ 100X penicillin/streptomycin and $50 \mathrm{ml}$ horse serum; Gibco; Thermo Fisher Scientific, Grand Island, NY, USA). Cells were counted and plated in $10 \%$ glial MEM in polylysine-coated 6- and 96-well cell culture plates respectively $\left(5 \times 10^{6}\right.$ cells per well in 6 -well culture plates) for $3 \mathrm{~h}$. The medium was then replaced and cultures were maintained in neurobasal media supplemented with B-27, N2 nutritional supplements, $0.5 \mathrm{mM}$ glutamine and $0.05 \mathrm{mg} / \mathrm{ml}$ penicillin/streptomycin (all Invitrogen; Thermo Fisher Scientific, Inc.). After $48 \mathrm{~h}$, cultures were subjected to treatment with different concentrations of $\mathrm{MPP}^{+}(0,50,100,200,400$, 800 and 1,600 $\mu \mathrm{M})$. Cell viability was evaluated at 24 and $48 \mathrm{~h}$ after $\mathrm{MPP}^{+}$treatment using a Cell Counting kit-8 (Dojindo Molecular Technologies, Inc., Kumamoto, Japan). From the results, $800 \mu \mathrm{M} \mathrm{MPP}^{+}$was selected for use in subsequent experiments.

In the later experiments, neuron cultures were divided into four groups: Blank control, model $\left(\mathrm{MPP}^{+}\right), \mathrm{Scb}\left(\mathrm{Scb}+\mathrm{MPP}^{+}\right)$ and TFP5 (TFP5 $+\mathrm{MPP}^{+}$) groups. For pretreatment, PBS, PBS, $0.2 \mathrm{mM}$ Scb and $0.2 \mathrm{mM}$ TFP5 was applied, respectively. At $3 \mathrm{~h}$ after the start of pretreatment, $800 \mu \mathrm{M} \mathrm{MPP}^{+}$was added to the neurons, with the exception of those in the blank control group. Neuronal culture was continued for an additional $24 \mathrm{~h}$. Finally, the viability of the neurons was determined by CCK8 assay, as described above. All cell toxicity assays were performed in triplicate more than twice to ascertain reproducibility.

Cell membrane penetration detection. In order to observe the cell membrane penetration of TFP5, $3 \mathrm{~h}$ after the application of 0.2 mM TFP5, neurons cultures (400-500 neurons $/ \mathrm{mm}^{2}$ ) were washed with $1 \mathrm{X}$ PBS at room temperature for $3 \mathrm{~min}$. 1X PBS was removed and $40 \mathrm{ml} \mathrm{4 \%} \mathrm{paraformaldehyde} \mathrm{was}$ added, then the neurons were fixed with paraformaldehyde at room temperature for $10 \mathrm{~min}$. Following this, neurons were washed with 1X PBS for $3 \mathrm{~min}$, the nuclei were stained with 4',6-diamidino-2-phenylindole and observed with a fluorescence microscope at $3 \mathrm{~h}$ after the application of TFP5.

Western blot analysis. For preparation of whole well extract, neurons were sonicated in sample buffer $(30 \mathrm{~mm}$ Tris- $\mathrm{HCl}$, $\mathrm{pH} 6.8,5 \%$ glycerol, $1.6 \%$ sodium dodecyl sulfate and $2.5 \%$ $\beta$-mercaptoethanol), and concentrated by centrifugation at $12,000 \mathrm{x} g$ for $20 \mathrm{~min}$ at $4^{\circ} \mathrm{C}$. The supernatant was obtained and the concentration of protein was determined by BCA protein assay (Pierce Biotechnology, Inc., Rockford, IL, USA). Samples were then boiled at $95^{\circ} \mathrm{C}$ for 5 min and separated by electrophoresis on $12 \%$ acrylamide gels, with proteins subsequently blotted to polyvinylidene fluoride membrane (Immobilon TM-P; Millipore Corporation, Bedford, MA, USA). The membrane was then incubated with primary antibodies in Tris-buffered saline and Tween 20 (TBS-T) buffer containing $3 \%$ bovine serum albumin (Sigma-Aldrich) at $4^{\circ} \mathrm{C}$ overnight. The following antibodies were used: Phospho-MEF2D 
(pSer444) antibody (1:1,000; SAB4503938; Sigma-Aldrich), p35/25 (C64B10) antibody (1:1,000; 2680S; Cell Signaling Technology, Inc., Beverly, MA, USA) and $\beta$-actin antibody (1:5,000; SC-130301; Santa Cruz Biotechnology, Inc., Dallas, TX, USA). The blots were then washed in TBS-T buffer and incubated for $1 \mathrm{~h}$ with horseradish peroxidase-labeled goat anti-mouse IgG or goat anti-rabbit IgG (1:2,000; BA1054; Wuhan Boster Biological Technology, Ltd., Wuhan, China). Immunoreactive protein was visualized using an enhanced chemiluminescence method (Amersham ECL Plus; GE Healthcare Life Sciences, Chalfont, UK). Chemiluminescence was detected by exposing the membrane in a Kodak in-vivo Imaging System FX Pro suite from $30 \mathrm{sec}$ to 15 min (Kodak, Rochester, NY, USA). Protein load was periodically monitored via the immunodetection of $\beta$-actin. Semi-quantitative values were obtained using Quantity One ${ }^{\circledR}$ software (version 4.62; Bio-Rad Laboratories, Inc., Hercules, CA, USA). Results are expressed as arbitrary units of optical density.

Statistical analysis. Data are expressed as means \pm standard deviation. Statistical analysis was performed using SPSS 16.0 statistical software (SPSS, Inc., Chicago, IL, USA). One-way analysis of variance (ANOVA) and the Scheffé post-hoc comparison method were applied to compare the means of groups and $\mathrm{P}<0.05$ was considered to indicate a statistically significant difference among the compared groups.

\section{Results}

$\mathrm{MPP}^{+}$induces neurotoxicity in mouse cortical neurons in a dose- and time-dependent manner. To evaluate the neurotoxicity of different concentrations of $\mathrm{MPP}^{+}$in mouse cortical neurons, various concentrations of $\mathrm{MPP}^{+}$were applied to primary mouse cortical neurons cultured in 96-well plates, and after 24 and $48 \mathrm{~h}$ a CCK8 assay was employed to evaluate the viability of neurons. The results show that as the $\mathrm{MPP}^{+}$ concentration increased from 0 to $1,600 \mu \mathrm{M}$ and the exposure time was prolonged, neuronal variability decreased in a doseand time-dependent manner (Fig. 1). The viabilities of neurons treated with $0,50,100,200,400,800$ and $1,600 \mu \mathrm{M} \mathrm{MPP}^{+}$for $24 \mathrm{~h}$ were as follows: $99 \pm 2,93 \pm 4,82 \pm 5,75 \pm 4,68 \pm 7,53 \pm 6$ and $36 \pm 6 \%$, respectively. When the treatment time was prolonged to $48 \mathrm{~h}$, the neuronal viabilities at these concentrations of $\mathrm{MPP}^{+}$were: $100 \pm 0,93 \pm 4,87 \pm 4,77 \pm 5,51 \pm 3,36 \pm 3$ and $22 \pm 4 \%$, respectively. One-way ANOVA indicated that the neuronal viability was significantly different among the groups $(\mathrm{P}<0.01)$, and the median lethal dose $\left(\mathrm{LD}_{50}\right)$ of $\mathrm{MPP}^{+}$to mouse cortical neurons after $24 \mathrm{~h}$ exposure was $\sim 800 \mu \mathrm{M}$. This concentration was chosen for establishing the in vitro PD model.

TFP5 suppresses $\mathrm{MPP}^{+}$-induced neurotoxicity in primary mouse cortical neurons. The protective function of TFP5 in $\mathrm{MPP}^{+}$-treated primary mouse cortical neurons was tested. The results demonstrated that the viability of neurons in the model group was significantly decreased compared with that in the blank control group (55 \pm 5 vs. $100 \pm 0 \%$; $\mathrm{P}<0.01)$, and TFP5 $(0.2 \mathrm{~mm})$ significantly inhibited $\mathrm{MPP}^{+}$-induced toxicity compared with $\mathrm{Scb}$ peptide $(98 \pm 2$ vs. $54 \pm 4 \% ; \mathrm{P}<0.01)$ and compared with the model group $(98 \pm 2$ vs. $55 \pm 5 \%$; $\mathrm{P}<0.01$; Fig. 2).

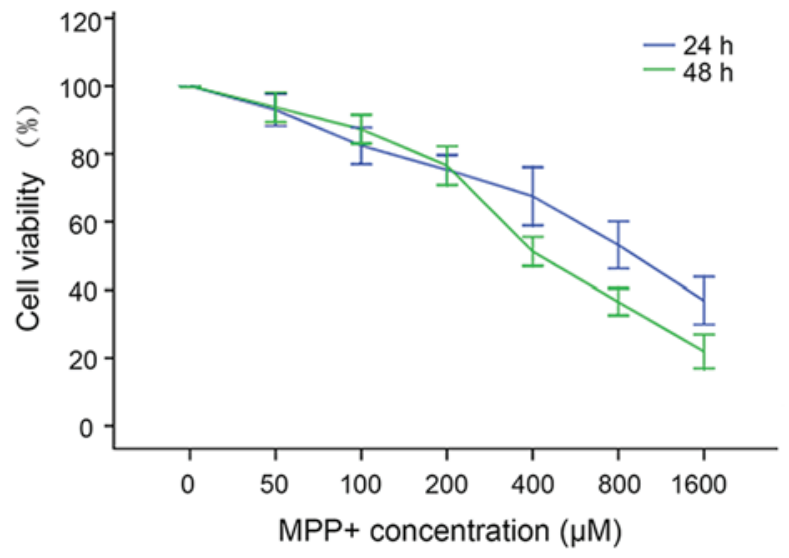

Figure $1 . \mathrm{MPP}^{+}$induced neurotoxicity in mouse cortical neurons in a doseand time-dependent manner. The viability of mouse cortical neurons treated with different concentrations of $\mathrm{MPP}^{+}$ranging from 0 to $1,600 \mu \mathrm{M}$ for $24 \mathrm{~h}$ (blue line) and $48 \mathrm{~h}$ (green line) are shown. Cell viability was analyzed by CCK8 assay. Data are expressed as mean \pm standard deviation $(n=3)$. One-way analysis of variance testing showed that the neuron viability of all groups was different significantly $(\mathrm{P}<0.01) . \mathrm{MPP}^{+}, 1$-methyl-4-phenylpyridinium ion; CCK8, Cell Counting kit-8.

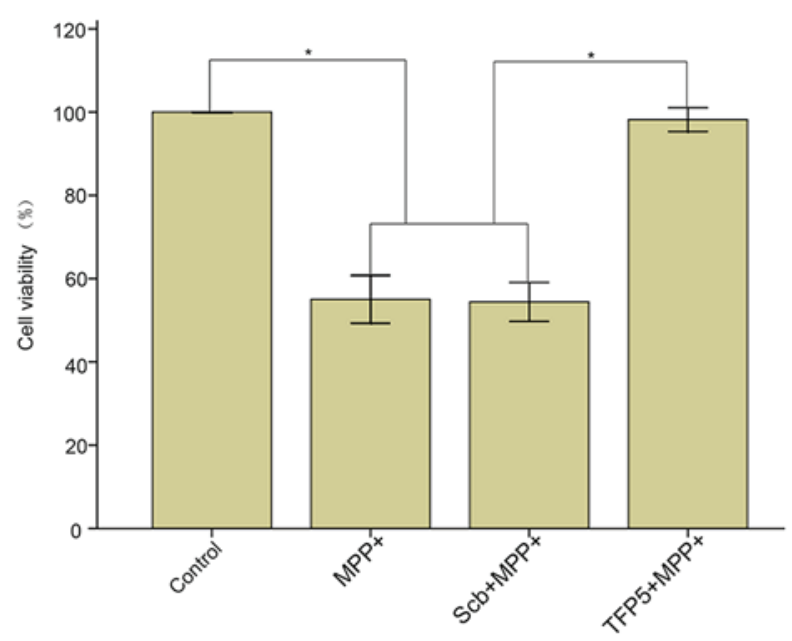

Figure 2. TFP5 protects against $\mathrm{MPP}^{+}$-induced neurotoxicity. CCK8 assay indicated that $\mathrm{MPP}^{+}$induced primary cultured mouse cortical neuron death, which was rescued by TFP5 pre-treatment. One-way analysis of variance and post hoc analysis showed that differences in neuron viability between the blank control and $\mathrm{MPP}^{+}$groups and between the TFP5 $+\mathrm{MMP}^{+}$and $\mathrm{MPP}^{+}$groups were significantly different $\left({ }^{*} \mathrm{P}<0.01\right)$. Data are expressed as the mean \pm standard deviation $(n=3)$. TFP5, modified $\mathrm{p} 5$ peptide; $\mathrm{MPP}^{+}$ 1-methyl-4-phenylpyridinium ion; Scb, scrambled peptide; CCK8, Cell Counting kit-8.

TFP5 successfully penetrates through the cell membrane of primary mouse cortical neurons. Whether TFP5 is able to penetrate through cell membranes following application to cultured primary neurons was investigated. The neurons were observed with a fluorescence microscope $3 \mathrm{~h}$ after the application of TFP5. As indicated in Fig. 3, green fluorescence was visible in the cytoplasm of neurons. Thus, TFP5, with FITC as a fused fluorescence label, successfully penetrated through the cell membranes of primary mouse cortical neurons.

TFP5 inhibits $M P P^{+}$-induced hyperphosphorylation of MEF2D in mouse cortical neurons. Cdk5/p25 formation and 
A

TFP5 sequence

FITC-GGGKEAFWDRCLSVINLMSSKMLQINAYARAARRAARR

B

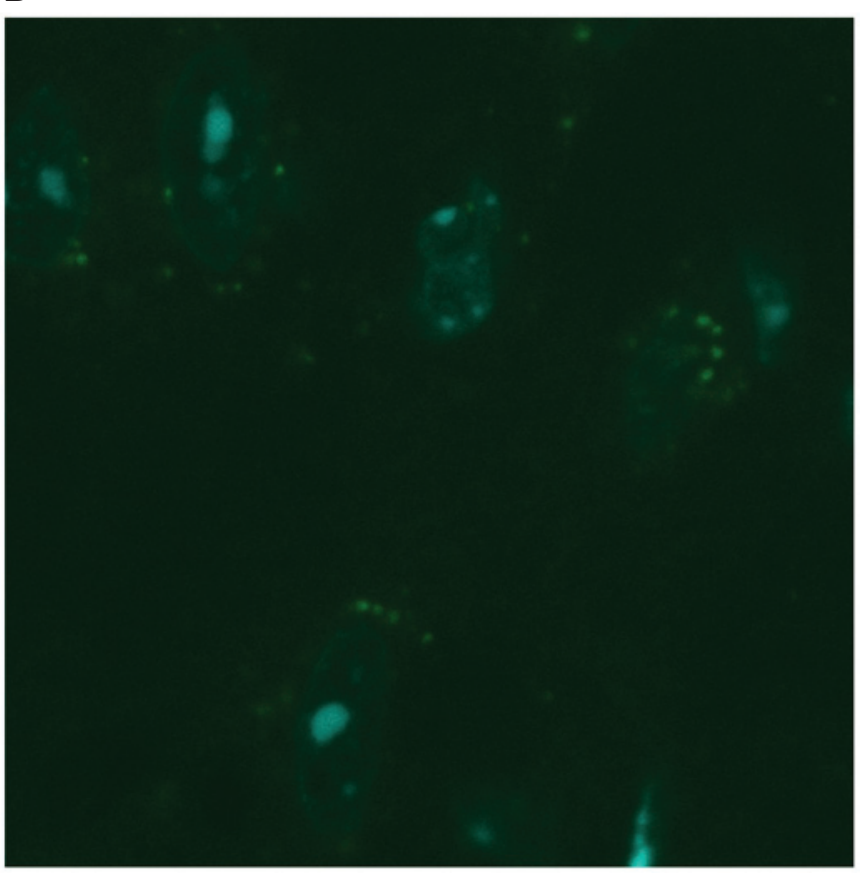

Figure 3. TFP5 distribution in cultured neurons. (A) Sequence of the TFP5 peptide, conjugated with an FITC tag (in green) at the $\mathrm{N}$ terminus attached with a linker (in black) to 55 (in red). At the $\mathrm{C}$ terminus of TFP5 is a Tat protein transduction domain peptide to ease entry into neurons. (B) Fluorescence microscopy of primary mouse cortical neurons to which $0.2 \mathrm{mM}$ TFP5 was applied. TFP5 (green fluorescence) penetrated the cell membrane and was located in cytoplasm of the neurons at $3 \mathrm{~h}$ after application to the culture. TFP5, modified p5 peptide; FITC, fluorescein isothiocyanate; Tat, transactivator of transcription; $\mathrm{MPP}^{+}$, 1-methyl-4-phenylpyridinium ion.

the subsequent hyperphosphorylation of MEF2D are involved in the pathology of PD disease and PD model mice (11). To investigate the mechanism underlying the protective effect of TFP5 on dopaminergic neuron death in PD, p25 expression and the phosphorylation status of MEF2D were analyzed in $\mathrm{MPP}^{+}$-treated mouse cortical neurons. As indicated in Fig. 4, $\mathrm{MPP}^{+}$application induced p35 cleavage in mouse cortical neurons and induced the phosphorylation of MEF2D $(81 \pm 10$ vs. $22 \pm 2 \%$; $\mathrm{P}<0.01)$. TFP5 did not alter $\mathrm{MPP}^{+}$-induced $\mathrm{p} 25$ expression, but significantly inhibited the phosphorylation of MEF2D compared with the model group ( $25 \pm 12$ vs. $81 \pm 10 \%$; $\mathrm{P}<0.01)$. Neither PBS nor Scb peptide had any effect on $\mathrm{p} 25$ expression or the phosphorylation level of MEF2D.

\section{Discussion}

Cdk5/p25 hyperactivity is involved in the development of neurodegenerative diseases such as AD and PD (20,21). The specific $\mathrm{Cdk} 5 / \mathrm{p} 25$-inhibiting peptide $\mathrm{p} 5$ has been demonstrated to be protective in $\mathrm{AD}(22)$. It has been demonstrated that $\mathrm{MPP}^{+}$ induces oxidative damage by selectively inhibiting the activity of mitochondrial complex I in dopaminergic cells, or cortical neurons when used at a relatively high dose (23); therefore, such treated cells serve as a well-established PD model (24). In the present study, the neuroprotective role of a derivative of
A
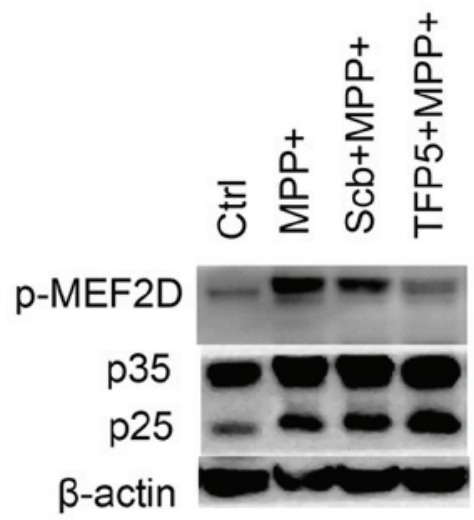

B

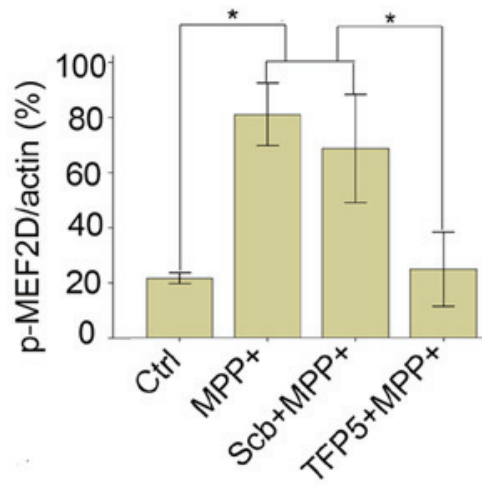

C

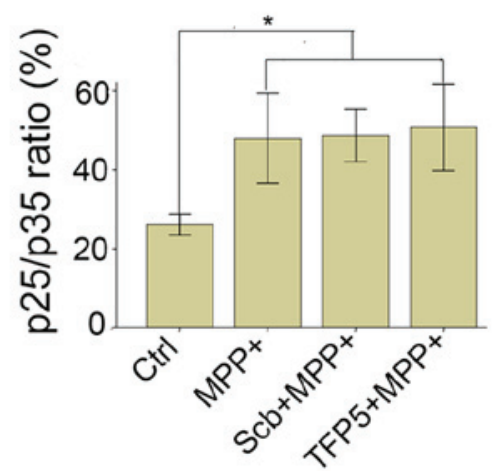

Figure 4. TFP5 inhibited hyperphosphorylation of MEF2D in primary cultured mouse cortical neurons in an $\mathrm{MPP}^{+}$-induced in vitro model of Parkinson's disease. (A) Representative western blot showing that $24 \mathrm{~h} \mathrm{MPP}^{+}$ treatment induced p35 cleavage in the cortical neurons, p25 was elevated in all treated groups, and TFP5 inhibited the MPP ${ }^{+}$-induced phosphorylation of MEF2D. $\beta$-actin was a sample loading control. Densitometric measurements of (B) the phosphorylated (p-)MEF2D/ $/$-actin ratio and $(C)$ the $\mathrm{p} 25 / \mathrm{p} 35$ ratio from three separate experiments. Data are expressed as mean \pm standard deviation $(n=3)$. One-way analysis of variance indicated significant differences between groups ( $\mathrm{P}<0.01)$. TFP5, modified $\mathrm{p} 5$ peptide; Scb, scrambled peptide; $\mathrm{MPP}^{+}$, 1-methyl-4-phenylpyridinium ion; MEF2D, myocyte enhancer factor 2 .

the peptide $\mathrm{p5}$, namely TPF5, was further investigated in this $\mathrm{MPP}^{+}$-induced cellular PD model. The mechanism by which TFP5 decreases Cdk5 activity is hypothesized to proceed via the competitive inhibition of formation of the $\mathrm{Cdk} 5 / \mathrm{p} 25$ complex, which in turn inhibits the hyperphosphorylation of MEF2D.

The Cdk5/p25 complex is involved in the loss of dopaminergic neurons from the $\mathrm{SNpc}$, which is responsible for the symptoms of PD patients and animal models (7). P5 has been demonstrated to inhibit $\mathrm{Ckd} 5 / \mathrm{p} 25$ interaction and decrease 
Cdk5 activity in AD (22). Therefore, it may be hypothesized that 55 could play the same role in a PD model. To facilitate passage through the blood brain barrier and/or cell membranes, the 55 peptide was used in the modified form TFP5. The results showed that TFP5 was able to penetrate the cell membrane of neurons and was distributed around the nucleus. Further in vivo experiments using an MPTP-induced PD model are now ongoing in the present authors' laboratory.

Hyperphosphorylation of MEF2D is important in the pathological pathway of PD $(8,13)$. As a downstream target of Cdk5/p25, how the phosphorylation status of MEF2D was affected by the inhibition of Cdk5/p25 activity was investigated. The results of the present study indicate that TFP5 reduced the hyperphosphorylation of MEF2D and thus may have prevented neuronal apoptosis.

A limitation of this study is the lack of activity measurements of Cdk5/p25 due to experimental limitations. However, the specific inhibitory effect of TFP5 on Cdk5/p25 has been well documented in the literature $(20,25)$. Inflammatory factors also play an important role in the pathology of PD. The ability of TFP5 to interfere with inflammation in PD requires investigation in further studies. Another focus of future studies is the protective role of TFP5 in a MPTP-induced mouse model of PD.

In conclusion, the findings of the present study provide new information that increases our understanding of the neuroprotective role of TFP5 and its potential for use in clinical trials.

\section{Acknowledgements}

This study was supported by grants from the Nature Science Foundation of Guangdong Province (grant no. S2012010008993), the National Nature Science Foundation of China (NSFC81271430) and the Scientific Research Foundation of the First People's Hospital of Chenzhou (CZYY20130009).

\section{References}

1. Rascol O: Drugs and drug delivery in PD: Optimizing control of symptoms with pramipexole prolonged-release. Eur J Neurol 18: (Suppl 1): S3-S10, 2011.

2. Salat D and Tolosa E: Levodopa in the treatment of Parkinson's disease: Current status and new developments. J Parkinsons Dis 3: 255-269, 2013.

3. Wood-Kaczmar A, Gandhi S and Wood NW: Understanding the molecular causes of Parkinson's disease. Trends Mol Med 12: $521-528,2006$.

4. Su SC and Tsai LH: Cyclin-dependent kinases in brain development and disease. Annu Rev Cell Dev Biol 27: 465-491, 2011.

5. Lee MS, Kwon YT, Li M, Peng J, Friedlander RM and Tsai LH: Neurotoxicity induces cleavage of p35 to p25 by calpain. Nature 405: 360-364, 2000.

6. Alvira D, Ferrer I, Gutierrez-Cuesta J, Garcia-Castro B, Pallàs M and Camins A: Activation of the calpain/cdk5/p25 pathway in the girus cinguli in Parkinson's disease. Parkinsonism Relat Disord 14: 309-313, 2008.
7. Hattori $\mathrm{N}$ and Mizuno Y: Pathogenetic mechanisms of parkin in Parkinson's disease. Lancet 364: 722-724, 2004.

8. Smith PD, Crocker SJ, Jackson-Lewis V, Jordan-Sciutto KL, Hayley S, Mount MP, O'Hare MJ, Callaghan S, Slack RS, Przedborski S, et al: Cyclin-dependent kinase 5 is a mediator of dopaminergic neuron loss in a mouse model of Parkinson's disease. Proc Natl Acad Sci USA 100: 13650-16655, 2003.

9. Wong AS, Lee RH, Cheung AY, Yeung PK, Chung SK, Cheung ZH and Ip NY: Cdk5-mediated phosphorylation of endophilin B1 is required for induced autophagy in models of Parkinson's disease. Nat Cell Biol 13: 568-579, 2011.

10. Avraham E, Rott R, Liani E, Szargel R and Engelender S: Phosphorylation of Parkin by the cyclin-dependent kinase 5 at the linker region modulates its ubiquitin-ligase activity and aggregation. J Biol Chem 282: 12842-12850, 2007.

11. Smith PD, Mount MP, Shree R, Callaghan S, Slack RS, Anisman H, Vincent I, Wang X, Mao Z and Park DS: Calpain-regulated p35/cdk5 plays a central role in dopaminergic neuron death through modulation of the transcription factor myocyte enhancer factor 2. J Neurosci 26: 440-447, 2006.

12. Camins A, Verdaguer E, Folch J, Canudas AM and Pallàs M: The role of $\mathrm{CDK} 5 / \mathrm{P} 25$ formation/inhibition in neurodegeneration. Drug News Perspect 19: 453-460, 2006.

13. Zhang L, Liu W, Szumlinski KK and Lew J: p10, the N-terminal domain of $\mathrm{p} 35$, protects against CDK5/p25-induced neurotoxicity. Proc Natl Acad Sci USA 109: 20041-20046, 2012.

14. Rosales JL and Lee KY: Extraneuronal roles of cyclin-dependent kinase 5. Bioessays 28: 1023-1034, 2006.

15. Lopes JP and Agostinho P: Cdk5: Multitasking between physiological and pathological conditions. Prog Neurobiol 94: 49-63, 2011.

16. Piedrahita D, Hernández I, López-Tobón A, Fedorov D, Obara B, Manjunath BS, Boudreau RL, Davidson B, Laferla F, Gallego-Gómez JC, et al: Silencing of CDK5 reduces neurofibrillary tangles in transgenic alzheimer's mice. J Neurosci 30: 13966-13976, 2010.

17. Shukla V, Zheng YL, Mishra SK, Amin ND, Steiner J, Grant P, Kesavapany S and Pant HC: A truncated peptide from p35, a Cdk5 activator, prevents Alzheimer's disease phenotypes in model mice. FASEB J 27: 174-186, 2013.

18. Gong CX and Iqbal K: Hyperphosphorylation of microtubule-associated protein tau: A promising therapeutic target for Alzheimer disease. Curr Med Chem 15: 2321-2328, 2008

19. Xu SY, Wu YM, Ji Z, Gao XY and Pan SY: A modified technique for culturing primary fetal rat cortical neurons. J Biomed Biotechnol 2012: 803930, 2012.

20. Shukla V, Skuntz S and Pant HC: Deregulated Cdk5 activity is involved in inducing Alzheimer's disease. Arch Med Res 43: 655-662, 2012

21. Wen Z, Shu Y, Gao C, Wang X, Qi G, Zhang P, Li M, Shi J and Tian B: CDK5-mediated phosphorylation and autophagy of RKIP regulate neuronal death in Parkinson's disease. Neurobiol Aging 35: 2870-2880, 2014.

22. Zheng YL, Amin ND, Hu YF, Rudrabhatla P, Shukla V, Kanungo J, Kesavapany S, Grant P, Albers W and Pant HC: A 24-residue peptide ( $\mathrm{p} 5$ ), derived from $\mathrm{p} 35$, the $\mathrm{Cdk} 5$ neuronal activator, specifically inhibits Cdk5-p25 hyperactivity and tau hyperphosphorylation. J Biol Chem 285: 34202-34212, 2010.

23. Namura I, Douillet P, Sun CJ, Pert A, Cohen RM and Chiueh CC: $\mathrm{MPP}^{+}$(1-methyl-4-phenylpyridine) is a neurotoxin to dopaminenorepinephrine- and serotonin-containing neurons. Eur J Pharmacol 136: 31-37, 1987.

24. Xie HR, Hu LS and Li GY: SH-SY5Y human neuroblastoma cell line: In vitro cell model of dopaminergic neurons in Parkinson's disease. Chin Med J (Engl) 123: 1086-1092, 2010.

25. Binukumar BK, Zheng YL, Shukla V, Amin ND, Grant P and Pant HC: TFP5, a peptide derived from $\mathrm{p} 35$, a Cdk5 neuronal activator, rescues cortical neurons from glucose toxicity. J Alzheimers Dis 39: 899-909, 2014. 